\title{
“Passport To The World 1" Based On Communicative Language Teaching Principle
}

\author{
Ayu Putri Prihatiningsih, Joko Nurkamto, Teguh Sarosa \\ English Education Department \\ Teacher Training and Education Faculty \\ Sebelas Maret University of Surakarta
}

Email:ayuhaumea@gmail.com

\begin{abstract}
The purposes underlying this study are (1) to describe an English textbook entitled "Passport to the World 1" in general; (2) to analyze the quality of the English textbook in developing communicative tasks and types of communicative materials. This research used a descriptive method. The data source of this research is the textbook for seventh grade of Junior High School, published in 2009 by PT Tiga Serangkai Pustaka Mandiri. In collecting data, this study takes four of ten units in the textbook randomly. The study uses theory of Cunningsworth (1995) to analyze the textbook in general and Communicative Language Teaching principles to analyze the tasks and material of the textbook. The result of the study shows that (1) the description of the textbook in general is fairly good (62.5\%); (2) the quality of communicative tasks is good $(68.7 \%)$, and the quality of types of material in CLT is very good (75.03\%). The textbook has all criteria of communicative tasks and materials, but each unit of the the textbook is still not complete. It means that the textbook is appropriate to be used and it will be better if the teacher also completes each unit which is not appropriate communicative criteria by using other sources in order to develop students' communicative competence.
\end{abstract}

Keyword: textbook, communicative task, communicative material.

\section{INTRODUCTION}

The importance of learning English makes it taught from the Elementary School to Senior High School. The goverment expects that the students can use English to communication. Some factors that influence English teaching and learning process are a teacher and instructional material. In supporting the teaching learning process, the presence of a book is necessary to consider as stated by Brown (1994: 145), the most obvious and most common form of material support for language comes through textbooks. It means that a textbook is the most common factor to support the success of teaching learning process.

Nowaday, the center of the teaching learning is the student, not the teacher. Teaching and learning is not how the teacher has good teaching, but how the student can learn well. Here it is important for the teacher in facilitate some materials for the student. Classroom activities should parallel the 'real world' as closely as possible. Since language is a tool of communication, methods and materials should concentrate on the message, not the medium (Clark, 1987: 51). Teacher can use some materials 
in teaching students such as video, book, cassete or card

Textbook is an instructional material that teacher uses in teaching students. Textbook becomes a popular instructional material because it provides an outline that the teacher can use in planning course, units, and lesson. It summarizes a great deal of pertinent information and enables the students to take home in convenient form most of materials they need to learn for the course. A textbook provides a common resource for all students to follow and provides the teacher with idea regarding the organization of information and activities. The textbook includes other teaching aids, such as summaries and review questions and relieves the teacher of having to prepare material for the course, thus allowing more time to prepare the lesson. (Ornstein, and Lasley (2000: 229).

According to Cunningsworth (1995: 17), textbooks help the learner to learn in a number of ways. They select the items to be learned (grammar, functions, skill, etc), break them down into manageable units and sequences them in a way which is designed to lead from the familiar to the unfamiliar and from easier to more difficult items in terms of "learnability". Textbooks also embody certain learning styles and strategies, which can influence how individul students, go about their own learning. Textbooks can promotelearning by contributing to student moivation. An interesting textbook well presented, with variety of topics and activities can be a powerful factor in strengthening the motivation of the lerners, and often teachers too. As a result, the teacher prepare students who have the competences as described in the competence standards and basic competences to get that the teacher decides the indicator of competence achievement.
Then the teacher must select the textbook used in order that the students can reach the indicators.

Cunningswoth (1995: 15) explain that selecting textbook involves matching the material against the context, which is going to be used. There is no textbook will be absolutely ideal for particular group for students, but the aim is to find the best possible fit, together with potential for adapting or supplementing parts of the material which is inadequate or unsuitable. There are eight criterias in evaluating and selecting a good textbook; aims and approaches, design and organising, language content, skills, methodology, teacher's book and practical consideration.

English learning has purpose to make the students able in communication. As a result the curriculum is based on communicative competence as the main point of Communicative Language Teaching. It is an approach in language teaching which uses communicative competence as the goal and develops procedures for teaching of four language skills that acknowledge the interdepence of language and communication (LarsenFreeman, 2000: 121).

The use of Communicative Language Teaching approach will develop the students' communicative competence by using English expression. To stimulate the learners, textbook should stimulate communications between learners. Some activities will encourage learners to think about the nature of language and ways of learning imply a more critical and reflective learner role than those in which the learner is memorizing or manipulating language (Nunan, 1989: 83).

According to Nunan (1989: 12), CLT is something of a misnomer to talk about the 'communicative approach' as there is a 
family of approaches, each member of which claims to be communicative. It means that CLT is an approach not a method. Similiar with Nunan, Richard and Rogers state that many proponent considered CLT as an approach rather than a method that aims to make communicative competence the goal of language teaching and develop procedures for the teaching of the four language skils that acknowledge the interdepence of language and communication. (Richards and Rogers, 1998: 66).

Littlewood (1981: 1) argues that one of the most characteristic features of communicative language teaching pays systematic attention to functional as well as structural aspecs of language. It means using procedures where learners work in pairs or groups employing available language resources in problem-solving task in order to get the goal of language learning, that is communicative ability.

From the definitions above, it can be concluded that CLT is an approach of language teaching whose purpose is to make the students active, interact with other people, either in the flash, through pair and group work.

One of the most important components in communicative language teaching is activities. It is an open question to what extent this coursebook can include real communicative activities (Cunningsworth, 117). There are some theories in of communicative activities: information gap principle, jigsaw principle, task continuity principle, information transfer principle, authentic principle, problem solving, game and word in context.

Wright (1987) in Nunan suggests that task needs minimally contain just two elements. One of them is input data which may be provided by materials. Richards and
Rogers mention 3 types of material used in CLT namely text-based materials, taskbased materials, and realia.

Based on those explanation above, the purpose of the study are: (1) to describe an English textbook for seventh grade Junior High School entitled "Passport to the World 1 " in general, (2) to analyze task in English textbook for seventh grade Junior High School entitled "Passport to the World 1" and (3) to analyze types of CLT materials used in English textbook for seventh grade Junior High School entitled "Passport to the World 1".

\section{RESEARCH METHODS}

The study uses descriptive method as the proper method. It just focuses on an English textbook entitled "Passport to the World 1". The data were taken from the English textbook entitled "Passport to the World 1" written by Djatmika, Agus Dwi Priyanto, and Ida Kusuma Dewi, published by PT. Tiga Serangkai Pustaka Mandiri 2009 by randomly. The writer cuts a paper into pieces. Then, the writer writes the namber 1-10. Number 1 for chapter 1 , number 2 for chapter 2 and so on. The number is rolled and shaked. The writer takes four of them. They are Unit 2 (Hi, This is Rudi), Unit 4 (Do It But Don't Do That!), Unit 7 (I Like...), and Unit 10 (It's 7.8 Feet Tall)

The study has four steps in analyzing the data. The steps are: a) defining criteria, b) subjective analysis, c) objective analysis, d) matching. The next step is scoring and percentage of analysis textbook in general. The study uses Criterion Referenced Evaluation as proposed by Burhan Nurgiantoro to calculate the percentage how far the textbook applies the criteria good coursebook, to calculate the persentage of quality communicative task in textbook 
"Passport to the World 1" and to analyze whether "Passport to the World 1" uses types of CLT materials.

\section{RESEARCH FINDINGS AND DISCUSSIONS}

"Passport to the World 1" is an English textbook written by Djatmika, Agus Dwi Priyanto and Ida Kusuma Dewi and published in 2009 by PT. Tiga Serangkai Pustaka Mandiri. The book is white and $20 \mathrm{x}$ $27.5 \mathrm{~cm}$ that consists of 194 pages. The book is designed to develop English skill of Junior High School's students in easy and fun way to introduce English as means of communication. The content of the textbook consists of concept map, warming up, activity, listening practice, working in group, get more, check the expression, grammar check, grammar practice, fun time, creative corner, game, grammar summary, don't know yet?, compact dictionary, reflection, and unit evaluation and semester exam.

Concept map draws materials in a unit globally. Warming up opens unit with a pre-activity before students learn the main materials. Activity demands the students to reach the level of competence needed. Listening practice invites the student to practice with listening materials. Working in group asks the students to work in group. Get more gives deeper and more specific materials for the students. Check the expression contains the expressions used in the related materials. Grammar check assists students in learning English grammar. It is designed to support the material contents of every unit. Grammar practice makes sure that students understand the grammar presented. Fun time means enjoying moment. Students can relax while doing the activities because it is formed to give more knowledge in enjoyable way. Creative corner challenges students in developing the creativity. Game is full of exciting activity. It forces students to be more active. Grammar summary summarizes the material in grammar check. "Don't know yet?" adds some newest additional information related to the theme. It talks about culture, art, science, and so on. Compact dictionary gives references to the difficult words. Reflection evaluates the students about the progress of learning. Unit evaluation and semester exam are the parameters for the teacher in analyzing the student's competence.

The contents in the textbook also consists of 10 units. They are Unit 1: Hi, I'm Nina, Unit 2: Hi, This is Rudi, Unit 3: What Does She Look Like, Unit 4: Do It But Don't Do That, Unit 5: I'm Sorry, Unit 6: Do You Get Up Early?, Unit 7: I Like.., Unit 8: My Classroom, Unit 9: Sorry, I Don't Know What You Mean, Unit 10: It's 7.8 Feet Tall. In each unit divided into five parts. They are Warming Up, Listen and Talk, Read and Write, Cooling Down, and Evaluation.

The next part is analyzing textbook in general. The writer uses theory of Cunningswoth (1995). There are eight points in selecting good textbook. They are aims and approach, design and organization, language content, skills, topic, methodology, teachers' books, practical consideration.

Aims and approach are what is the textbook for, what the situation of the learner, and what is needed by the students. Here, the writer finds that "Passport to the World 1" is the guiding materials for Junior High School students. It can be seen on the preface of the textbook: The purpose of the textbook is the students be able to develop their communication competence in either spoken or writen modes. It is suitable with the competence standard and basic 
competence of material for English in Junior High School. We can see that the target for students in Junior High School is called functional level, that is the students can use English for communication to solve the problem in daily activities such as read a newspaper, magazines, symbol, or instruction.

Actually in design and organization, the textbook has some components such as tape script, tasks, activities, picture, sign, etc. The content is organized skills (listening, reading, speaking, reading) with acceptable for the students in junior high school. The textbook also completed by concept map to make the teacher easy to find the way around the coursebook. But the total course package does not provide in design of the textbook. Cunningsworth said that the components make up the total course package are consist of students' book, teachers' books, workbooks, cassetes, etc. "Passport to the World 1" is only a students' book.

In language content, the first consideration is what grammar items are included and how far they correspond to learner need. In "Passport to the World 1", grammar is taught in each chapter. When introducing new grammar the textbook explains the form first, and then gives practice. The next important of language content is vocabulary. In "Passport to the World I" vocabulary is shown by read it and find the meaning. The textbook does not indicate how the pronunciation of the words. The student still guided by the teacher if they want to know the pronunciation of the words.

"Passport to the World I" covers four skills, listening, speaking, reading and writing. They are divided into two parts, listen and talk, and read and write. In the textbook, the material (ex. Listening) is not recorded, but it reads by the teacher. In teaching speaking, "Passport to the World I" covers activity such as interviewing friends and making a conclusion. In reading, there is a text and a photograph about a family. Then, the students have to answer the question based on information of the text in a table card. Cunningsworth said that all the students need in reading is access to suitable texts and reference material, such as dictionary or world list. In "Passport to the World 1" uses text about introducing a family in descriptive text and gives dictionary in each unit. In writing this book give a box to write the paragraph, for example the students take a picture, then put it into the box. After that the students make a paragraph based on the questions.

The textbook consists of many varieties topic that is suitable for the level of the students in Junior High School. The topic is based on the experiences in day-today life. In almost all units the textbook has games that make the students relax in accepting the material. It can be seen that a good point of the textbook is that there is a section to introduce some habits of cultures of native English speakers.the objectives of the section is to prepare the students for the cultural shocs when they really interact with the native English speakers.

Communicative approach is used in the thextbook that appropriate with learning situation in real-life. The level that is expected of the textbook are shown in the first cover in each unit. The textbook has reflection part to evaluate the students in the progress learning.

Teachers' book is one of coursebook components package. It recognizes the unique function of the teacher in certain aspects of teaching, such as guiding, monitoring and encouraging students, explaining difficulties, and responding the 
questions. It promotes the development of learners independence. In "Passport to the World I" does not provide teachers' book. The book only focuses on students in Junior High School.

The textbook represents good value for money, because the cost is Rp 20,000 when the writer buys the textbook. Here the textbook does not show the cost on the cover. The textbook published by Tiga Serangkai Pustaka Mandiri, so it is easy to obtain the textbook. In appearance the textbook is strong and full color.

From the explanation above, it can be seen that the textbook has five from eight criteria, so : $\frac{5}{A} \times 100 \%=62.5 \%$. It can be concluded that the textbook is fairly good in general.

The next section the writer analyzes four chapters of "Passpot to the World 1" to clarify the quality of the textbook in communicative task and communicative material used. Those are:

Unit 2 entitled Hi, This is Rudi! consists of 20 tasks. According to the classification of communication tasks, there are four tasks in this chapter. They are information gap principle, information transfer principle, task continuity and games. So, in analyzing communicative task this chapter has 4 scores. Based on the classification of types of CLT materials, there are two types in this chapter. They are task-based materials and realia. The scoring for types of CLT material in this unit is 2 scores.

Unit 4 entitled Do It, But Don't Do That! Consists of 20 task. According the clasification of communicative tasks, there are information gap principle, authentic principle, information transfer principle, task continuity, word in context, and games. So, this chapter has 6 scores. Based on the clasification of types of CLT materials there are task based material, text based material, and realia. The scoring for types of CLT material in this chapter is 3 scores.

Unit 7 entitled I Like... consists of 20 tasks. According to classification of communicative tasks, there are problem solving principle, information gap principle, word in context, task continuity, information transfer principle, and game. So, this chapter has 6 scores. Based on the classification types of CLT materials, there are task based material and text based material. The score for types of CLT material is 2 scores.

Unit 10 entitled It's 7.8 Feet Tall consists of 18 tasks. According to the classification of communicative tasks, there are problem solving principle, information gap principle, information transfer principle, task continuity, jigsaw principle, and game. In information gap principle, the writer is not clear in giving information. There should be instructions that teacher gives the facts about the Bengal tigers to the student A. Then the teacher give other informations to the student $\mathrm{B}$ thats the student $\mathrm{A}$ do not know yet. The student A and B ask and give informations about the Bengal tigers. From

Table 1. The level of quality for communicative tasks

\begin{tabular}{lccccc}
\hline No. & Unit & $\begin{array}{c}\text { Number of } \\
\text { Task }\end{array}$ & Score & Percentage & $\begin{array}{c}\text { Level of } \\
\text { Quality }\end{array}$ \\
\hline 1. & 2 & 4 & 4 & $50 \%$ & Average \\
2 & 4 & 6 & 6 & $75 \%$ & Very Good \\
3. & 7 & 6 & 6 & $75 \%$ & Very Good \\
4. & 10 & 6 & 6 & $75 \%$ & Very Good \\
& Average & 5.5 & 5.5 & $\mathbf{6 8 . 7 5 \%}$ & Good
\end{tabular}


the explanations, this chapter has 6 scores. Based on the classification types of CLT materials, there are text based material and realia. The score for types of CLT material in this chapter is 2 scores.

Table 1 provides the average scores and percentages of the units in "Passport to the World 1" that are analyzed in this study. good coursebook. The textbook has covered five of eight criteria, they are aims and approach, language content, skills, topic and methodology. The result of the study stated that percentage of quality in general coursebook is $62.5 \%$. It can be concluded that the textbook is fairly good in general quality.

\begin{tabular}{lccccl}
\multicolumn{6}{c}{ Table 2. The level of quality for Types of CLT Materials } \\
\hline No. & Unit & $\begin{array}{c}\text { Number of Types of } \\
\text { CLT Materials }\end{array}$ & Score & Percentage & $\begin{array}{c}\text { Level of } \\
\text { Quality }\end{array}$ \\
\hline 1. & 2 & 2 & 2 & $66.7 \%$ & Good \\
2 & 4 & 3 & 3 & $100 \%$ & Very Good \\
3. & 7 & 2 & 2 & $66.7 \%$ & Good \\
4. & 10 & 2 & 2 & $66.7 \%$ & Good \\
& Average & 2.25 & 2.25 & $\mathbf{7 5 . 0 3 \%}$ & Very Good \\
\hline
\end{tabular}

Based on the table above, it can be concluded that the average score for communicative tasks of "Passport to the World 1" is 5.5 and the percentage of communicative tasks is $68.7 \%$. It means that the quality of "Passport to the World 1" is good in developing the communicative tasks. This section provides the average and percentage for types of CLT materials, which are shown in table 2.

Based on the table 2, it can be concluded that the average score for types of CLT materials of "Passport to the World 1" is 2.25 and the average percentage of communicative tasks is $75.03 \%$. It means that the quality of "Passport to the World 1" is very good in developing the types of CLT materials.

\section{CONCLUSIONS AND SUGGESTIONS}

After analyze "Passport to the World 1" an English textbook for junior high school, the study presents some conclusions as follow:

First, the study finds that the textbook is not complete for criteria of a
Second, the study finds that there are seven of eight points of communicative tasks used in "Passport to the World 1", they are Information Gap Principle, Jigsaw Principle, Task Continuity Principle, Information Transfer Principle, Authentic Principle, Problem Solving Principle, Games and Word in Context. The result of the study stated that percentage of communicative tasks developed in the textbook is $68.7 \%$. It can be concluded that the textbook is good in developing the communicative tasks suggested by the expert.

Third, the study finds that there are all types of material in CLT used in "Passport to the World 1", they Text Based Material, Task Based Material and Realia. The result of the study stated that percentage of communicative material in the textbook is $75.03 \%$. It can be concluded that the textbook is very good in developing the types of CLT material.

The result of the study shows that the textbook is good in developing communicative tasks and very good 
developing types in CLT material. Based on the result and conclusion above, "Passport to the Worls 1" can be used for teaching English in Junior High School, but the teacher better complete communicative tasks by using other sources in making perfect communicative tasks. The textbook can motivate the students in Junior High School. Motivation is one of the most powerful forces for good and effective learning and can often be more important than other factors, including teaching method (Cunningsworth, 1995: p.17).

After finishing the study and finding the result of the analysis, the writer has some suggestions. The writer of "Passport to the World 1" can complete communicative tasks in each chapter to make the students in Junior High School practice English more communicative. The number of tasks for the chapters is enough for represent the material in those chapters. The writer of the textbook can increase it.

For the teachers, they have important roles in the implementation of CLT. They have to be creative in preparing and presenting the material to be taught in the classroom. The teachers are expected to select communicative tasks and materials in textbook to give challenge the student to grow the motivation of the students. Abbs and Freebairn (1990) in Adibatul suggest that, for motivation to be sustained, students need to be continually challenged, either linguistically or intellectually, through texts, activities and tasks. Students easily lose concentration if they are allowed to be passive, or if the lessons are to easy or dull. Even at beginners' level, the subject matter must engage the students' minds and challenge them to think. It means Abbs and Freebairn acknowledge that the need for textbook to challenge students in order to keep up their motivation.
Other researches can analyze the other textbooks and compare them. They can analyze the textbook by other theory to complete the content analysis that has been done. So if there is a better textbook, they can recommend to use the textbook.

\section{BIBLIOGRAPHY}

Adibatul Mustanaah. 2006. Thesis. A content Analysis on Let's Talk. An English Textbook for the FirstYear of SMPN 4 Surakarta, Academic Year 2005/2006. English Department: Sebelas Maret University.

Brumfit, C. J., and K. Johnson. (eds.). 1979. The Communicative Approach to Language Teaching. Oxford: Oxford University Press.

BSNP. 2006. Panduan Penyusunan Kurikulum Tingkat Satuan Pendidikan. Minister of National Education

Burhan Nurgiantoro. 1987. Penelitian dalam Pengajaran Bahasa dan Sastra. Yogyakarta: BPFE Yogyakarta.

Clark, J. 1987. Curriculum Renewal in School Foreign Language Learning. Oxford: Oxford University Press.

Cunningswoth, Allan. 1995. Choosing Your Course Book. Oxford; Heinemann

Djatmika, Agus Dwi Priyanto, and Ida Kusuma Dewi. 'Passport to the World 1'A fun and Easy English Book. PT. Tiga Serangkai Pustaka Mandiri.

Firman F. 2004. Unpublished manuscript, Thesis: An Evaluation on Official English Textbook for Senior High School. English Department: Sebelas Maret University.

Freeman. 1986. Technique and Principles in Language Teaching.London: Oxford University Press.

Hadi, Sutrisno. 2004. Methodology Research. Yogyakarta: penerbit Andi Yogya 
Harmer, J. 1997. Designing Task for the Communicative Classroom. Cambridge: Cambridge University Press.

Littlewood, W. 1981.Communicative Language Teaching - An Introduction. Cambridge: Cambridge University Press.

Nunan, David. 1998. Designing Task for The Communicative Classroom. Cambridge; Cambridge University Press

Prihananto, W. 2008. Thesis. Content Analysis on English Junior High School Textbook, Let's Talk, by Bachtiar Bima Mustriana and Cicik Kurniawati. English Department. Sebelas Maret University.
Richards, Jack, C. and Rodgers, Theodore, S. 1986. Approaches and Methods in Language Teaching: A Description and Analysis. Cambridge: Cambridge University Press.

Richards, Jack, C. and Rodgers, Theodore, S. 2001. Approaches and Methods in Language Teaching. Cambridge: Cambridge University Press.

Suharsimi Arikunto. 1998. Prosedur Penelitian; Suatu Pendekatan Praktek. Jakarta; Rineka Cipta.

Toms, Colin. 2004. Internet Teaching Articles. Available at: http://www.asian-efljournal.com $/ 04$ ct.pdf Retrieved at: March 212013 